\title{
Pemahaman Tentang Berbagai Faktor Yang Dapat Mempengaruhi Struktur Modal Pada Perusahaan Tekstil di Bursa Efek Indonesia
}

\author{
MURNAWATI \\ Dosen Tetap Universitas Lancang Kuning \\ Jln. Yos Sudarso Km 08 Rumbai Pekanbaru Telp. (0761) 52581 \\ E-mail : murnawati@unilak.ac.id
}

\begin{abstract}
The era of globalization is very rapid. Many companies are growing and growing in each field of business they live. This causes the business world competition becomes increasingly tight. This study aims to determine various factors that can affect the Capital Structure of Textile companies in Indonesia Stock Exchange. Various ways done by the company to be the best. One way to be superior to other companies is to increase the company's value and the prosperity of the company owner. This research uses 3 variables, namely independent variable and dependent variable. The independent variables in this study are Asset Structure, and Sales Growth. While the dependent variable in this study is Capital Structure. The population in this study are 10 Textile companies in Indonesia Stock Exchange. Classic Assumption Testing using Normality Test, Multicolinearity Test, Autocorrelation Test and Heteroscedasticity Test. Testing Hypothesis data using Test F, Test $\mathrm{T}$ and Test Coefficient of Determination. Based on the results of the study can be concluded that the Asset Structure, Company Size and Sales Growth simultaneously significant effect on Capital Structure. While the Variable Size Company and Sales Growth did not significantly influence the Capital Structure of Textile companies in Indonesia Stock Exchange.
\end{abstract}

Keywords: Capital Structure, Asset Structure, Company Size and Sales Growth.

Perusahaan dalam menjalankan usahanya sejalan dengan pengembangan yang dialami, selalu membutuhkan tambahan modal. pada saat perusahaan didirikan, pemilik bisa menentukan sumber modal apa yang dipakai, apakah semuanya bersumber dari modal saham biasa atau perlu ada hutang jangka panjang. Setiap keputusan yang diambil tentang sumber modal selalu ada dampaknya. Misalnya bila sumber modal saham biasa ada kewajiban membayar deviden dan keputusankeputusan kebijakan atau pengelolaan dari pemegang saham perlu diperhatikan

Struktur modal adalah masalah yang sangat penting bagi perusahaan, karena struktur modal perusahaan merupakan cerminan dari kondisi financial perusahaan tersebut. Tinggi rendahnya struktur modal tentunya akan mempengaruhi para investor ketika akan menanamkan modalnya di dalam suatu perusahaan. Tidak hanya bagi para investor, kondisi financial perusahaan juga akan mempengaruhi pemikiran para pemegang saham, apakah kebijakan yang dilakukan oleh perusahaan yang dalam hal ini dipegang oleh manajer keuangan kemakmuran para pemegang saham atau tidak. Secara umum, faktor-faktor yang berpengaruh terhadap keputusan struktur modal baik faktor yang berhubungan langsung dengan aktivitas financial perusahaan maupun yang tidak langsung, seperti stabilitas penjualan, struktur aktiva, laverage operasi, tingkat pertumbuhan, profitabilitas, pajak, pengendalian, sikap manajemen, sikap pemberi pinjaman, kondisi pasar, kondisi internal perusahaan dan fleksibilitas keuangan.

Perkembangan Bursa Efek Indonesia memiliki pengaruh ganda dalam pembangunan nasional. Dampak pengerahan dana masyarakat ke sektor produktif akan meningkatkan pruduksi, memperluas kegiatan lembaga yang terkait seperti akuntan publik, notaris, lembaga keuangan perbankan dan perdagangan efek. Selain itu dengan perkembangan Bursa Efek Indonesia 
diharapkan menghilangkan monopoli sumber modal dan monopoli kepemilikan perusahaan. Melalui Bursa Efek Indonesia diharapkan dapat menata kembali struktur modal lebih baik.

Perusahaan Manufaktur yang terdaftar di Bursa Efek Indonesia sangatlah banyak, disini penulis memilih meneliti perusahaan-perusahaan Tekstil. Perusahaan Textile yang Go Public ada 12 perusahaan

Perusahaan pada umumnya akan mempertimbangkan faktor-faktor berikut ini dalam melakukan keputusan struktur modal yaitu tingkat bunga, stabilitas dari "Earning", susunan dari aktiva, kadar risiko dari aktiva, besarnya jumlah modal yang dibutuhkan, keadaan pasar modal, sifat manajemen, besarnya suatu perusahaan (Riyanto;2009;296).

Menurut Ahmad Rodoni dan Herni Ali $(2010 ; 137)$, struktur modal adalah proporsi dalam menentukan pemenuhan kebutuhan belanja perusahaan dimana dana yang diperoleh menggunakan kombinasi atau paduan sumber yang berasal dari dana jangka panjang yang terdiri dari dua sumber utama yakni yang berasal dari dalam dan luar perusahaan. Memahami dasar-dasar teori struktur modal sangatlah penting, karena pemilihan bauran pendanaan target, maka saham dijual (Margaretha;2011;112). Struktur modal. (financing mix) merupakan inti strategi bisnis secara keseluruhan. Struktur modal adalah bauran sumber pendanaan permanen (jangka panjang) yang digunakan perusahaan (Sawir;2004;43) Struktur modal menggambarkan pembiayaan permanen perusahaan yang terdiri utang jangka pendek, utang jangka panjang dan modal sendiri. Jika utang sesungguhnya (realisasi) berada dibawah target, pinjaman perlu ditambah. Jika rasio utang melampaui target, maka saham dijual (Margaretha;2011;112).

Struktur modal adalah kombinasi atau perimbangan antara utang dan modal sendiri (saham preferen dan saham biasa) yang digunakan perusahaan untuk merencanakan mendapatkan modal. (Ambarwati:2010;1).

Menurut (Riyanto;2009;296-300), struktur modal suatu perusahaan dipengaruhi oleh banyak faktor dimana faktor-faktor yang utama ialah:

1. Tingkat Bunga. Pada waktu perusahaan merencanakan pemenuhan kebutuhan modal adalah sangat dipengaruhi oleh tingkat bunga yang berlaku pada waktu itu. Tingkat bunga akan mempengaruhi pemilihan jenis modal apa yang akan ditarik, apakah perusahaan akan mengeluarkan saham atau obligasi.

2. Stabilitas dari "Earning". Stabilitas dan besarnya "earning" yang diperoleh oleh suatu perusahaan akan menentukan apakah perusahaan tersebut dibenarkan untuk menarik modal dengan beban tetap atau tidak. Suatu perusahaan yang mempunyai "earning" yang stabil akan selalu dapat memenuhi kewajiban finansialnya sebagai akibat dari penggunaan modal asing. Sebaliknya perusahaan yang mempunyai "earning" tidak stabil dan "unpredictable" akan menanggung risiko tidak dapat membayar beban bunga atau tidak dapat membayar angsuran-angsuran utangnya pada tahun-tahun atau keadaan yang buruk.

3. Susunan dari Aktiva. Kebanyakan perusahaan industri di mana sebagian besar dari modalnya tertanam dalam aktiva tetap (Fixed Assets), akan mengutamakan pemenuhan kebutuhan modalnya dari modal yang permanen, yaitu modal sendiri, sedangkan modal asing sifatnya adalah sebagai pelengkap. 
4. Kadar Risiko dari Aktiva. Tingkat atau kadar dari setiap aktiva di dalam perusahaan adalah tidak sama. Makin panjang jangka waktu penggunaan suatu aktiva di dalam perusahaan, makin besar derajat resikonya. Dengan perkembangan dan kemajuan teknologi dan ilmu pengetahuan yang tak ada henti-hentinya, dalam artian ekonomis dapat mempercepat tidak digunakannya suatu aktiva, meskipun dalam artian teknis masih dapat digunakan. Besarnya Jumlah Modal yang dibutuhkan

Besarnya jumlah modal yang dibutuhkan juga mempunyai pengaruh terhadap jenis modal yang akan ditarik. Apabila jumlah modal yang dibutuhkan sekiranya dapat dipenuhi hanya dari satu sumber saja, maka tidaklah perlu mencari sumber lain. Sebaliknya apabila jumlah modal yang dibutuhkan sangat besar, sehingga tidak dapat dipenuhi dari satu sumbet saja (misalnya dengan saham biasa), maka perlulah dicari sumber yang lain (misalnya dengan saham preferen dan obligasi)

1. Keadaan Pasar Modal. Keadaan pasar modal sering mengalami perubahan disebabkan karena adanya gelombang konjungtur. Pada umumnya apabila gelombang meninggi, para investor lebih tertarik untuk menanamkan modalnya dalam saham. Berhubung dengan itu maka perusahaan dalam rangka usaha untuk mengeluarkan atau menjual securities haruslah menyesuaikan dengan keadaan pasar modal tersebut

2. Sifat Manajemen. Sifat manajemen akan mempunyai pengaruh yang langsung dalam pengambilan keputusan mengenai cara pemenuhan kebutuhan dana. Seorang manajer yang bersifat optimis yang memandang masa depannya dengan cerah, yang mempunyai keberanian untuk menanggung resiko yang besar, akan lebih berani untuk membiayai pertumbuhan penjualannya dengan dana yang berasal dari hutang meskipun metode pembelanjaan dengan utang ini memberikan beban finansiil yang tetap. Sebaliknya seorang menejer yang bersifat pesimis, yang serba takut untuk menanggung risiko, akan lebih suka membelanjai pertumbuhan penjualannya dengan dana yang berasal dari sumber intern atau dengan modal saham yang tidak mempunyai beban finansial yang tetap.

3. Besarnya Suatu Perusahaan. Suatu perusahaan yang besar dimana sahamnya tersebar sangat luas, setiap perluasan modal saham hanya akan mempunyai pengaruh yang kecil terhadap kemungkinan hilangnya atau tergesernya kontrol dari pihak dominan terhadap perusahaan yang bersangkutan. Sebaliknya perusahaanyang kecil dimana sahamnya hanya tersebar dilingkungan kecil, penambahan jumlah saham akan mempunyai pengaruh yang besar terhadap kemungkinan hilangnya kontrol pihak dominan terhadap perusahaan yang bersangkutan. Dengan demikian, pada perusahaan yang besar di mana sahamnya tersebar sangat luas akan lebih berani mengeluarkan saham baru dalam memenuhi kebutuhannya untuk membiayai pertumbuhan penjualan di bandingkan dengan perusahaan yang kecil.

4. Struktur Aktiva. Menurut Weston dan Brigham $(2005 ; 175)$ pengertian struktur aktiva dapat diartikan yaitu:"Perimbangan atau perbandingan antara aktiva tetap dan

p.ISSN: 2407-800X e.ISSN: 2541-4356 
total aktiva."Sedangkan menurut Syamsuddin (2002;9), struktur aktiva memiliki pengertian sebagai berikut:"Penentuan berapa besar alokasi dana untuk masing-masing komponen aktiva, baik dalam aktiva lancar maupun dalam aktiva tetap". Aktiva adalah manfaat ekonomi yang mungkin terjadi di masa depan, yang diperoleh atau dikendalikan oleh entitas sebagai hasil dari transaksi atau peristiwa di masa lalu. Dalam neraca, aktiva dapat diklasifikasi menjadi lancar dan tidak lancar (Hery;2014;112).

\section{METODE}

Didalam penelitian ini penulis tidak melakukan penelitian secara langsung, tetapi dengan mengambil data-data perusahaan Tekstil yang terdaftar di Bursa Efek Indonesia (BEI) pada tahun 2010-2014. Adapun yang menjadi objek penelitian dalam penelitian ini adalah struktur modal, struktur aktiva, ukuran perusahaan dan pertumbuhan penjualan perusahaan Tekstil di Bursa Efek Indonesia (BEI).

Populasi yang digunakan dalam penelitian ini adalah seluruh perusahaan Tekstil yang terdaftar di Bursa Efek Indonesia (BEI) pada tahun 2010-2014. Dalam penelitian ini, penulis menggunakan sampel dengan kriteria-kriteria sebagai berikut:

1. Perusahaan Tekstil yang terdaftar di Bursa Efek Indonesia selama periode 2010 hingga tahun 2014.

2. Perusahaan yang telah menerbitkan laporan keuangan dari tahun 2010-2014 dengan lengkap.

3. Perusahaan yang memiliki data yang lengkap selama periode penelitian untuk faktor-faktor yang diteliti, yaitu Struktur Aktiva, Ukuran Perusahaan dan Pertumbuhan Penjualan.

Teknik pengambilan sampel pada penelitian ini dilakukan dengan menggunakan metode purposive sampling yang artinya populasi yang memenuhi kriteria sampel yang dikehendaki peneliti dengan tujuan untuk mendapatkan sampel yang repsentative sesuai dengan kriteria yang ditentukan.

Sumber data yang digunakan dalam penelitian ini adalah data sekunder. Data sekunder adalah data yang telah dikumpulkan oleh lembaga pengumpul data dan telah dipublikasikan kepada masyarakat pengguna data laporan keuangan pada perusahaan tekstil yang terdaftar di Bursa Efek Indonesia (BEI) selama periode 20102014. (www.idx.co.id).

Analisis data merupakan salah satu tahap kegiatan penelitian berupa proses penyusunan dan pengolahan data. Metode analisis yang digunakan dalam penelitian ini adalah analisis linear berganda dan uji statistik t. Pemrosesan data menggunakan program aplikasi SPSS 17 (Statistical Product and Service Solution) sebelumnya lebih dikenal dengan nama Statistical Package for the Social Sciences.

\section{HASIL}

Dari analisis regresi akan diketahui ada tidaknya pengaruh dari varibel bebas, baik secara terpisah maupun secara bersama-sama. Analisis Regresi dapat dilakukan dengan cara sebagai berikut:

$$
\mathrm{Y}=1024,211+15,942 \mathrm{x}_{1}-184,952_{\mathrm{x} 2}-1,002_{\mathrm{x} 2}+\mathrm{e}
$$

\section{Dimana:}

$\mathrm{Y}=$ Struktur Modal

$\mathrm{X}_{1} \quad=$ Struktur Aktiva

$\mathrm{X}_{2}=$ Ukuran Perusahaan

$\mathrm{X}_{3} \quad=$ Pertumbuhan Penjualan

1. Dari persamaan regresi tersebut dapat dilihat bahwa nilai konstanta sebesar 1023,211. Hal ini diartikan bahwa terjadi pengaruh positif antara variabel struktur modal dengan variabel independen (struktur aktiva, ukuran perusahaan

p.ISSN: 2407-800X e.ISSN: 2541-4356 
dan pertumbuhan penjualan).

2. Nilai koefisien regresi variabel struktur aktiva sebesar 15,942. Nilai tersebut menunjukkan bahwa terjadi pengaruh positif antara variabel struktur aktiva dan variabel struktur modal. Kondisi ini dijelaskan jika terjadi kenaikan struktur aktiva sebesar 1 unit, maka struktur modal perusahaan akan naik sebesar 15,942.

3. Nilai koefisien regresi variabel ukuran perusahaan sebesar $-184,952$. Nilai tersebut menunjukkan bahwa terjadi pengaruh negatif antara variabel ukuran perusahaan dengan variabel struktur modal, kondisi ini dijelaskan jika terjadi kenaikan ukuran perusahaan sebesar 1 unit, maka struktur modal perusahaan akan turun sebesar 184,952.

4. Nilai koefisien regresi variabel pertumbuhan penjualan sebesar 1.002. nilai tersebut menunjukkan bahwa terjadi pengaruh negatif antara variabel pertumbuhan penjualan dengan variabel struktur modal. Kondisi ini dijelaskan jika terjadi kenaikan pertumbuhan penjualan sebesar 1 unit, maka struktur modal perusahaan akan turun sebesar 1,002

Nilai F hitung sebesar 9,000 lebih besar dari $\mathrm{F}$ tabel sebesar 2,81. Kondisi ini menunjukkan bahwa $\mathrm{F}$ hitung > F tabel sehingga diputuskan bahwa Ho ditolak dan Ha diterima. Artinya, variabel-variabel bebas (independen) secara bersama-sama berpengaruh signifikan terhadap variabel terikat (dependen). Sementara tingkat signifikannya adalah 0,000 dimana lebih kecil dari 0,05. Hal itu berarti struktur aktiva, ukuran perusahaan dan pertumbuhan penjualan berpengaruh signifikan terhadap struktur modal.

Pengujian hipotesis dalam penelitian ini menggunakan analisis regresi linier berganda yang bertujuan untuk melihat Jurnal Daya Saing pengaruh variabel independen terhadap pengaruh variabel dependen secara parsial (sendiri-sendiri) maupun secara simultan (bersama-sama). Pengujian hipotesis dilakukan dengan bantuan SPSS versi 17.

Pengujian ini dilakukan dengan melakukan uji signifikansi. Uji signifikansi (pengaruh nyata) variabel bebas (X) terhadap varibel terikat (Y) yang akan dilakukan dengan uji statistik dengan catatan hasil sig dibawah $\alpha$ (5\%) agar hipotesis dapat diterima. Untuk bisa menjawab hipotesis melalui pengujian secara parsial, perlu diketahui t tabel yang digunakan sebagai pembanding. Nilai $t$ tabel dilihat pada tabel t 0,025 (0,05:2) dengan Df $(n-k)=50-4=46$. Nilai tabel yang diperoleh sebesar 2,01290 hasil SPSS untuk analisis regresi berganda

\section{PEMBAHASAN}

Berdasarkan hasil penelitian dan pembahasan bahwa struktur aktiva berpengaruh signifikan terhadap Struktur Modal. Hal ini dapat dilihat dari nilai $\mathrm{t}$ hitung sebesar 5,162 lebih besar daripada $t$ tabel sebesar 2,01290. Sedangkan nilai signifikansi 0,000 lebih kecil daripada $\alpha$ 0,05 . Hasil ini dapat disimpulkan bahwa Struktur Aktiva berpengaruh signifikan terhadap Struktur Modal pada perusahaan Tekstil di Bursa Efek Indonesia.

Ukuran Perusahaan tidak berpengaruh signifikan terhadap Struktur Modal. Hal ini dapat dilihat dari nilai $t$ hitung sebesar -1,834 lebih kecil daripada $t$ tabel 2,01290. Sedangkan nilai signifikansinya 0,073 lebih besar daripada $\alpha$ 0,05. Hasil ini dapat disimpulkan bahwa Ukuran Perusahaan tidak berpengaruh signifikan terhadap Struktur Modal pada perusahaan Tekstil di Bursa Efek Indonesia.

Pertumbuhan Penjualan tidak berpengaruh signifikan terhadap Struktur Modal. Hal ini dapat dilihat dari nilai $t$ hitung sebesar -0,484 lebih kecil daripada $t$ tabel 2,01290. Sedangkan nilai

$$
\text { p.ISSN: 2407-800X e.ISSN: 2541-4356 }
$$


signifikansinya o,631 lebih besar daripada $\alpha$ 0,05 . Hasil ini dapat disimpulkan bahwa Pertumbuhan Penjualan tidak berpengaruh signifikan terhadap Struktur Modal pada perusahaan Tekstil di Bursa Efek Indonesia

Struktur Aktiva, Ukuran Perusahaan dan Pertumbuhan Penjualan secara simultan berpengaruh signifikan terhadap Struktur Modal. Hal ini dapat dilihat dari nilai $\mathrm{F}$ hitung sebesar 9,000 lebih besar daripada $\mathrm{F}$ tabel sebesar 2,81. Sedangkan nilai signifikansi nya sebesar 0,000 jauh lebih kecil dari nilai signifikan 0,05. Hasil ini dapat disimpulkan bahwa Struktur Aktiva, Ukuran Perusahaan dan Pertumbuhan Penjualan secara simultan berpengaruh signifikan terhadap Struktur Modal pada perusahaan Tekstil di Bursa Efek Indonesia.

Sebagai akhir dari penelitian ini, bahwa pihak manajemen perusahaan seharusnya mengetahui bahwa aktiva tetap sebagai jaminan hutang memegang peranan penting untuk memperoleh kredit. Perusahaan yang mempunyai aktiva tetap jangka panjang lebih besar, maka perusahaan tersebut akan banyak menggunakan hutang hipotik jangka panjang, dengan harapan aktiva tetap tersebut dapat digunakan untuk menutup tagihannya.

Hendaknya para menejer perusahaan dalam pengambilan setiap keputusan perusahaan dalam menentukan dari mana kebutuhan modalnya dipenuhi, maka perlu mempertimbangkan beberapa hal antara lain berapa besar kebutuhan dana tersebut, dalam bentuk apa sumber dana tersebut, dan berapa lama dana itu digunakan akan berpengaruh pada struktur modal perusahaan yang menunjukkan komposisi perbandingan sumber dana permanen yang digunakan oleh perusahaan dalam membiayai investasinya.

Penelitian ini hanya terbatas pada kajian empiris tentang faktor-faktor yang mempengaruhi struktur modal perusahaan tekstil yang go public di BEI, tetapi tidak sampai kepada pemecahan masalah tentang bagaimana dampak struktur modal itu sendiri terhadap kinerja perusahaan. Oleh karena itu, penelitian lain yang berminat terhadap permasalahan struktur modal perusahaan dapat mengembangkan penelitian ini dalam rangka untuk mengetahui dampak dari struktur modal yang digunakan perusahaan terhadap kinerja keuangan.

\section{SIMPULAN}

Berdasarkan uraian di atas, maka dapat disimpulkan variabel independen dalam penelitian ini adalah Struktur Aktiva, dan Pertumbuhan Penjualan. Sedangkan variabel dependen dalam penelitian ini adalah Struktur Modal. Populasi dalam penelitian ini adalah 10 perusahaan Tekstil di Bursa Efek Indonesia . Pengujian Asumsi Klasik menggunakan Uji Normalitas, Uji Multikolinearitas, Uji Autokorelasi dan Uji Heteroskedastisitas. Pengujian Hipotesis data menggunakan Uji $\mathrm{F}$, Uji $\mathrm{T}$ dan Uji Koefisien Determinasi. Berdasarkan hasil penelitian dapat disimpulkan bahwa Struktur Aktiva, Ukuran Perusahaan dan Pertumbuhan Penjualan secara simultan berpengaruh signifikan terhadap Struktur Modal. Sedangkan Variabel Ukuran Perusahaan dan Pertumbuhan Penjualan tidak berpengaruh siginifikan terhadap Struktur Modal pada perusahaan Tekstil di Bursa Efek Indonesia.

\section{DAFTAR RUJUKAN}

Alexandri, Moh Benny, 2008, Manajemen Keuangan Bisnis, Bandung, Alfabeta.

Ambarwati, Sri Dwi Ari, 2010, Manajemen Keungan Lanjut, Yogyakarta, Graha Ilmu.

Amstrong, Michael, 2005, Manajemen Sumber Daya Manusia, Jakarta, Elexmedia Komputindo.

p.ISSN: $2407-800 X$

e.ISSN: $2541-4356$ 
Astuti, Dewi, 2004, Manajemen Keungan Perusahaan, Jakarta, Ghalia Indonesia.

Brigham, Houston, 2001, Manajemen Keuangan edisi kedelapan buku II, Jakarta, Erlangga

, 2006, Dasar-dasar Manajemen Keuangan edisi Kesepuluh buku II, Jakarta, Salemba empat.

Brigham, Weston, 2005, Dasar-dasar Manajemen Keuangan, Edisi Kesembilan Jilid 2, Jakarta, Erlangga.

Darmawi, Herman, 2011, Manajemen Perbankan, Jakarta, Bumi Aksara.

Fahmi, Irham, 2011, Analisis Laporan Keuangan, Lampulo, ALFABETA.

Gitman, Lawrence J. 2003, Principle of Managerial Finance, Tenth Editi on, Person Education, Inc, United States.

Harmono, 2009, Manajemen Keuangan: berbasis balanced scorecard, Jakarta, Bumi Aksara.

Hery, 2014, Analisis Laporan Keuangan, Jakarta, Bumi Aksara.

Husnan, Suad, Enny Pudjiastuti, 2012, Dasar-dasar Manajemen Keuangan edisi keenam, Yogyakarta, UPP STIM YKPN.

Joni, lina, 2010, Faktor-faktor yang mempengaruhi struktur modal, jurnal bisnis dan akuntansi. Vol. 12, No. 2, Agustus, hal. 81-96.

Kasmir, 2000, Manajemen Perbankan, Jakarta, Raja Grafindo Persada.
Keown, Arthur J., Johm D. Martin, J William Petty dan David F. Scott, JR, 2005, Financial Management, edisi tujuh. Terjemahan oleh Chaerul D. Djakman dan Dwi Sulistyorini dari Basic Financial Management, Jakarta, Salemba Empat.

Margeretha, Farah, Aditya Rizky Ramadhan, 2010, Faktor-faktor yang mempengaruhi struktur modal pada industri manufaktur di bursa efek indonesia. Jurnal bisnis dan akuntansi, Vol.12, No.2, Agustus, hal. 119-130.

Margaretha, Farah, 2011, Manajemen Keuangan, Jakarta, Erlangga.

Santika, Rista Bagus, Bambang Sudiyatno, 2011, Menentukan Struktur Modal Perusahaan Manufaktur Di bursa Efek Indonesia. Jurnal dinamika keuangan dan perbankan. Vol. 3, No. 2, November, hal. 172-182

Riyanto, Bambang, 2009, Dasar-dasar Pembelanjaan Perusahaan edisi empat, Yogyakarta, BPFE.

Rodoni, Ahmad, Herni Ali, 2010, Manajemen Keuangan, Jakarta, Mitra Wacana Media.

Sartono, Agus, 2010, Manajemen Keuangan Teori dan Aplikasi, Yogyakarta, BPFE.

Sawir, Agnes, 2004, Kebijakan Pendanaan dan Restrukturisasi Perusahaan, Jakarta, Gramedia Pustaka Utama. 